\title{
Lymphocyte and Brain Neurotoxic Esterase: Dose and Time Dependence of Inhibition in the Hen Examined with Three Organophosphorus Esters
}

\author{
B. W. SCHWAB AND R. J. RICHARDSON ${ }^{1}$ \\ Toxicology Program, Neurotoxicology Research Laboratory, Department of Environmental and Industrial Health, \\ School of Public Health, The University of Michigan, Ann Arbor, Michigan 48109
}

Received July 3, 1985; accepted October 7, 1985

\begin{abstract}
Lymphocyte and Brain Neurotoxic Esterase: Dose and Time Dependence of Inhibition in the Hen Examined with Three Organophosphorus Esters. SCHWAB, B. W. AND RICHARDSON, R. J. (1986). Toxicol. Appl. Pharmacol. 83, 1-9. Certain organic phosphorus esters produce sensorimotor axonopathy in man and other species. There is an excellent correlation between the capacity of an organophosphorus compound to produce axonopathy and its ability to inhibit brain neurotoxic esterase (NTE) in hens. Because NTE is present in peripheral lymphocytes of both hen and man, it has been suggested that the lymphocyte enzyme might be useful both in experimental and clinical situations as an indicator of exposure to organophosphorus compounds producing axonopathy. Diethyl 4-nitrophenyl phosphate (paraoxon), tri-2-cresyl phosphate (TOCP), methyl 2,5-dichloro-4-bromophenyl phenylphosphonothionate (leptophos), and di- $n$-butyl-2,2-dichlorovinyl phosphate (di- $n$-butyl dichlorvos, DBDCV) were used to examine the relationship between lymphocyte and brain NTE inhibition in hens. As expected, paraoxon $(0.75 \mathrm{mg} / \mathrm{kg})$ did not inhibit NTE in brain or lymphocytes. TOCP (10 to $100 \mathrm{mg} / \mathrm{kg})$, leptophos (25 to $150 \mathrm{mg} / \mathrm{kg}$ ), and DBDCV (1.0 to $4.0 \mathrm{mg} / \mathrm{kg}$ ) inhibited both brain and lymphocyte NTE activity in a doserelated manner with good correlation of inhibition between tissues taken $24 \mathrm{hr}$ after exposure $\left(r^{2}=0.53\right.$ to $0.67 ; p<0.020$ to 0.001$)$. However, correlation of inhibition between tissues taken from animals killed $48 \mathrm{hr}$ after exposures was poor $\left(r^{2}=0.15\right.$ to $0.30 ; p<0.10$ to 0.05$)$, with consistently less inhibition of lymphocyte NTE relative to brain NTE. This study indicates that assay of lymphocyte NTE can provide a good monitor of exposure to axonotoxic organophosphorus compounds within $24 \mathrm{hr}$ between exposure and measurement. 1986 Academic Press, Inc.
\end{abstract}

Exposure to certain organic phosphorus esters produces sensorimotor neuropathy in humans. Adult laying hens (Gallus gallus domesticus) are used to provide a model of this condition for laboratory studies. Organophosphorus neuropathy is characterized morphologically as axonal degeneration, and both clinical and pathological alterations are delayed in onset, appearing 8 to 14 days following a single exposure to the toxic compound

${ }^{1}$ To whom all correspondence should be addressed: Toxicology: M7525, SPH II, The University of Michigan, Ann Arbor, Mich. 48109.
(Davis and Richardson, 1980; Johnson, 1982). Organophosphorus compounds producing axonopathy phosphorylate and thereby inhibit neurotoxic esterase (NTE), an enzyme first identified in hen brain. NTE is resistant to compounds such as diethyl 4-nitrophenyl phosphate (paraoxon) and tetraethyl pyrophosphate (TEPP), potent acetylcholinesterase inhibitors which do not produce neurodegeneration (Richardson, 1984). There is an excellent correlation between the capacity of an organophosphorus compound to inhibit hen brain NTE by 70 to $90 \%$ within 1 to 2 days after dosing and the production of clinically 
evident axonopathy some 2 weeks later (Lotti and Johnson, 1978, 1980), provided that the compound is aiso subject to cleavage of a side chain (aging) after the phosphorylation reaction has taken place (Johnson, 1974).

It was first shown in our laboratory that peripheral lymphocytes from the hen possess an esteratic activity which behaves in a manner identical to hen brain NTE with respect to in vitro substrate and inhibitor specificities, $\mathrm{pH}$ optima, and heat inactivation rates (Dudek and Richardson, 1980, 1982; Richardson and Dudek, 1983). NTE activity also exists in human lymphocytes and platelets (Bleeker et al., 1983; Richardson and Dudek, 1983; Bertoncin et al., 1985). If the time course and dose dependence of NTE inhibition in lymphocytes were similar to those in brain, the assay of lymphocyte NTE could be used to monitor exposure to axonotoxic organophosphorus compounds. We previously observed good correlation between brain and lymphocyte NTE inhibition $4 \mathrm{hr}$ following exposure of hens to a variety of NTE inhibitors (Dudek et al., 1979; Richardson and Dudek, 1983). This report further details the relationship between lymphocyte and brain NTE inhibition in response to organophosphorus compounds administered over a range of doses 24 and $48 \mathrm{hr}$ prior to assay.

\section{METHODS}

\section{Animals}

Adult (over 1 year old) white leghorn hens were obtained from Omega Chicks (Haslett, Mich.) at least 1 week prior to experimentation. The birds were maintained ( 3 to 4 per cage) in an air-conditioned room $\left(21\right.$ to $\left.23^{\circ} \mathrm{C}\right)$ on a 12-hr light-dark cycle in $0.8 \times 0.8 \times 0.9$-m stainless-steel cages with wire bottoms. Except for the fasting procedure prior to dosing, animals were given Purina Layena mash (Ralston Purina, St. Louis, Mo.) and tap water ad libitum.

\section{Chemicals}

Diethyl 4-nitrophenylphosphate, methyl 2,5-dichloro4-bromophenyl phenylphosphonothionate (leptophos, 98\% pure), and tri-2-cresyl phosphate (tri-o-cresyl phos- phate, TOCP, practical grade) were purchased from Sigma Chemical Company (St. Louis, Mo.), Chem Service, Inc. (West Chester, Pa.), and Eastman Kodak Company (Rochester, N. Y.), respectively. Di-n-butyl-2,2-dichlorovinyl phosphate (di-n-butyl dichlorvos, DBDCV, $95 \%$ pure) was custom synthesized by Ash-Stevens, Inc. (Detroit, Mich.). All other reagents for NTE and acetylcholinesterase assays were from Sigma Chemical Company, with the exception of 4-aminoantipyrine (Eastman Kodak Co., $98 \%$ pure), and were used without further purification. $N, N^{\prime}$-di-2-propyl phosphorodiamidofluoridate (mipafox) and phenyl valerate (PV) were synthesized and purified in our laboratory, according to methods described by Johnson (1977). Aqueous solutions were prepared with deionized-distilled water.

\section{Treatment Regimen}

Paraoxon, TOCP, and DBDCV were mixed with corn oil and introduced into the crop of hens (at least three per group) by steel gavage tube. Leptophos, a crystalline solid, was placed in gelatin capsules for introduction into the crop. All animals were fasted overnight prior to dosing and for $4 \mathrm{hr}$ postexposure; tap water was given ad libitum throughout. Control animals received an equivalent volume of corn oil vehicle $(2.0 \mathrm{ml} / \mathrm{kg}$ body wt) or an empty gelatin capsule. The dose of paraoxon was $0.75 \mathrm{mg} / \mathrm{kg}$ body wt. Other compounds were given in a range of doses (TOCP: 10,50 , and $100 \mathrm{mg} / \mathrm{kg}$; leptophos: $25,75,150$ $\mathrm{mg} / \mathrm{kg}$; and DBDCV: $1.0,2.0,3.0$, and $4.0 \mathrm{mg} / \mathrm{kg}$ ). Hens were killed by decaptiation 24 or $48 \mathrm{hr}$ after exposure.

\section{Tissue Preparation}

Lymphocytes. Blood was collected immediately after killing in heparinized plastic syringes, diluted 1.0/1.5 (v/ v) with room-temperature balanced salt solution (BSS; $0.01 \%$ D-glucose, $5.0 \mathrm{mM} \mathrm{CaCl}, 98.0 \mathrm{mM} \mathrm{MgCl}_{2}, 14.5$ mM Tris, $126.0 \mathrm{mM} \mathrm{NaCl}$, pH 7.6), and layered over FicollPaque density medium (Pharmacia Fine Chemicals, Piscataway, N.J.) in siliconized glass culture tubes. The tubes were centrifuged at $400 g_{\text {avg }}$ for $30 \mathrm{~min}$ at $20^{\circ} \mathrm{C}$. Lymphocytes gathered at the density interface were collected with plastic transfer pipets and placed in clean siliconized tubes. Cells were washed twice by suspension in BSS and centrifugation at $1000 \mathrm{gavg}_{\text {arg }}$ for $10 \mathrm{~min}$ at $20^{\circ} \mathrm{C}$. An aliquot of the final cell suspension was counted in a Model ZBI Coulter counter (Coulter Electronics, Hialeah, Fla.), and the final pellet was stored at $-80^{\circ} \mathrm{C}$ for no more than 24 hr prior to NTE assay. Lymphocyte pellets were allowed to thaw at room temperature, suspended in $2.00 \mathrm{ml}$ of 50 $\mathrm{mM}$ Tris- $\mathrm{HCl} / 0.20 \mathrm{mM}$ EDTA buffer ( $\mathrm{pH} 8.00$ at $25^{\circ} \mathrm{C}$ ), and sonicated for $10 \mathrm{sec}$ at a power output of $50 \mathrm{~W}$ with a Branson cell disrupter (Branson Sonic Power, Danbury, Conn.) fitted with a microtip which was immersed halfway into the suspension. The sonicate was then diluted with a 
sufficient volume of buffer to make a final concentration equivalent to $2.0 \times 10^{7}$ cells $/ \mathrm{ml}$.

Brain. Brains were rapidly removed from the skull at the time of death, blotted, weighed, and stored at $-80^{\circ} \mathrm{C}$ for no more than $24 \mathrm{hr}$ prior to NTE assay. After being allowed to thaw at room temperature, a $10 \%(\mathrm{w} / \mathrm{v})$ homogenate of brain in ice-cold $50 \mathrm{mM}$ Tris- $\mathrm{HCl} / 0.20 \mathrm{mM}$ EDTA buffer ( $\mathrm{pH} 8.00$ at $25^{\circ} \mathrm{C}$ ) was made with 10 strokes of a glass-teflon homogenizer (clearance approximately $0.25 \mathrm{~mm}$ ) fitted to a $2300 \mathrm{rev} / \mathrm{min}$ drill press. An aliquot of this homogenate was diluted with huffer to a tissue concentration of $2.0 \mathrm{mg} / \mathrm{ml}$.

\section{Biochemical Assays}

Neurotoxic esterase (NTE). NTE activity was assayed by colorimetric determination of the difference in phenol production by hydrolysis of PV between paired samples preincubated with paraoxon alone versus paraoxon plus mipafox. The procedure described by Johnson (1977) was modified and optimized for assay of both lymphocyte and brain NTE as follows: Tissue suspensions (equivalent to $1.0 \mathrm{mg}$ brain or $1.0 \times 10^{7}$ lymphocytes) in $0.50 \mathrm{ml}$ of buffer $(50 \mathrm{mM}$ Tris-HCl/0.20 mM EDTA, pH 8.00 at $25^{\circ} \mathrm{C}$ ) were mixed at zero time with $0.50 \mathrm{ml}$ of buffer containing either $200 \mu \mathrm{M}$ paraoxon or $200 \mu \mathrm{M}$ paraoxon plus $100 \mu \mathrm{M}$ mipafox and preincubated for exactly $20 \mathrm{~min}$ in a circulating water bath at $37^{\circ} \mathrm{C}$. PV ( $30 \mathrm{mg}$ dissolved in $1.0 \mathrm{ml}$ of dimethylformamide) was mixed with $30.0 \mathrm{ml}$ of $0.03 \%(w / v)$ aqueous Triton X-100 to make a micellar suspension and $1.00 \mathrm{ml}$ of this substrate mixture was added to the preincubate at the end of the 20 -min preincubation period. The reaction with substrate was allowed to proceed for exactly $30 \mathrm{~min}$ before stopping with $1.00 \mathrm{ml}$ of $1.0 \%$ $(\mathrm{w} / \mathrm{v})$ sodium dodecyl sulfate in $500 \mathrm{~mm}$ Tris- $\mathrm{HCl}$ buffer (pH 9.00 at $25^{\circ} \mathrm{C}$ ) containing $0.025 \%(\mathrm{w} / \mathrm{v})$ 4-aminoantipyrine. Color was developed at room temperature by adding $0.50 \mathrm{ml}$ of aqueous $0.40 \%(w / v)$ potassium ferricyanide and its absorbance was measured at $510 \mathrm{~nm}$ relative to deionized-distilled water in a Sequoia-Turner Model 340 spectrophotometer (Mountain View, Calif.). The absorbance difference between paired tubes preincubated with paraoxon alone versus paraoxon plus mipafox has been operationally defined to he due to hydrolysis of PV by NTE (Johnson and Richardson, 1983) and that value was used for specific activity determination. The molar absorptivity at $510 \mathrm{~nm}$ for the color product was determined from phenol standards to be $13,900 \mathrm{M}^{-1} \mathrm{~cm}^{-1}$. Because of the differential nature of the assay, tissue and reagent blanks are automatically subtracted. However, a reagent blank was routinely included as a check on the free phenol content of the substrate. Specific enzyme activity was calculated as nmol substrate hydrolyzed/min $x$ mg protein. Percentage enzyme inhibition was calculated by dividing the specific enzyme activity in individual tissues from treated animals by the mean specific activity in controls, subtracting this ratio from 1.00 , and multiplying by 100 .

Acetylcholinesterase. Brain acetylcholinesterase (AChE) was assayed by a modification of the method of Ellman et al. (1961), which has been previously described (Schwab and Murphy, 1981). Specific activity and enzyme inhibition were calculated as for NTE.

Protein. Protein was assayed using the Bio-Rad protein assay kit (Bio-Rad Laboratories, Richmond, Calif.) based on Bradford's dye-binding method (Bradford, 1976). Bovine serum albumin, fraction V (Sigma Chemical Co.), was used as a reference standard.

\section{Statistical Analysis}

To determine the statistical significance of the effect of paraoxon on brain AChE and brain lymphocyte NTE, unpaired $t$ tests were performed on the mean values obtained from tissues from treated versus control animals. Linear regression analysis was used to examine the correlation of NTE inhibition between tissues in animals given TOCP, leptophos, or DBDCV 24 or $48 \mathrm{hr}$ prior to killing. Brain inhibition (on the ordinate) was paired with lymphocyte inhibition (abscissa) from the same animal and regression lines were fitted to the data for each compound at each of the two time points using the method of least squares. Inference on the correlation of inhibition between tisues was made by $t$ test on the coefficient of determination $\left(r^{2}\right)$ of the regression lines. The null hypothesis in this test is that $r^{2}$ is equal to zero, i.e., that no correlation exists (Goldstein, 1964). Additionally, paired $t$ tests were performed on the values obtained for brain and lymphocyte NTE inhibition from each individual dosing group. Where mean values for data are presented, $\pm \mathrm{SE}$ is also given, with the number of observations (animals) indicated in parentheses; $p \leqslant 0.05$ was regarded as significant for $t$ tests.

\section{RESULTS}

All animals survived exposure to the test compounds. Dosed animals appeared to be less active in their cages than controls following dosing, but the only unequivocal clinical difference detected between treated and control animals occurred in paraoxon-dosed birds.

Paraoxon, $0.75 \mathrm{mg} / \mathrm{kg}$, inhibited brain AChE by $56 \pm 4 \%(n=16, p<0.001)$ and produced mild cholinergic signs (muscle fasciculations). This dose did not significantly inhibit either brain or lymphocyte NTE. Mean inhibition was $1 \pm 2 \%$ and $7 \pm 8 \%$ for brain and lymphocytes, respectively (relative to respective control activities of $51.2 \pm 0.85 \mathrm{nmol}$ 
and $9.92 \pm 0.68 \mathrm{nmol} \mathrm{PV}$ hydrolyzed $/ \mathrm{min}$ $\times \mathrm{mg}$ protein; $n=7$ ).

TOCP, leptophos, and DBDCV inhibited brain and lymphocyte NTE in a dose-responsive manner. When measured in tissues from animals killed $24 \mathrm{hr}$ after exposure, there was good agreement between brain and lymphocyte NTE inhibition. Coefficients of determination $\left(r^{2}\right)$ were $0.67(n=12, p<0.005), 0.53$ $(n=11, p<0.020)$, and $0.53(n=18, p$ $<0.001$ ) for TOCP, leptophos, and DBDCV regressions, respectively. Observations on tissues taken $48 \mathrm{hr}$ after exposure contrasted with the previous data. Coefficients of determination were lower in all regressions of $48 \mathrm{hr}$ data, and significantly different from zero only for DBDCV. The 48-hr $r^{2}$ values were $0.15(n$ $=22,0.05<p<0.10), 0.30(n=11,0.05$ $<p<0.10)$, and $0.30(n=16, p<0.05)$ for TOCP, leptophos, and DBDCV, respectively. Scattergrams and fitted regression lines of these data are presented in Figs. 1 to 3.

Mean NTE inhibition in brain and lymphocytes from the 10 dosing groups killed 24 hr aftcr exposure are presented in Figs. 4 to 6. NTE inhibition was similar for brain and lymphocytes in most groups. Statistically significant differences in brain versus lymphocyte inhibition were seen in only 2 of these groups (TOCP, $50 \mathrm{mg} / \mathrm{kg}$; and leptophos, $25 \mathrm{mg} / \mathrm{kg}$ ), and the direction of the differences were opposite. There were 9 dosing groups killed 48 hr after exposure (a $1 \mathrm{mg} / \mathrm{kg} \mathrm{DBDCV}$ group was included at $24 \mathrm{hr}$ but not at $48 \mathrm{hr}$ ). Mean inhibition data from these animals are presented in Figs. 4 to 6 . At $48 \mathrm{hr}$, the mean NTE inhibition value of lymphocytes was lower than that observed in brain in every case, with the difference being statistically significant in 4 of the groups (TOCP, 50 and $100 \mathrm{mg} / \mathrm{kg}$; leptophos, $75 \mathrm{mg} / \mathrm{kg}$; and DBDCV, $3 \mathrm{mg} / \mathrm{kg}$ ).

\section{DISCUSSION}

It would be useful in both clinical and experimental situations to be able to easily monitor absorption of axonotoxic organophosphorus compounds. Many of these compounds produce no acute signs, so that the
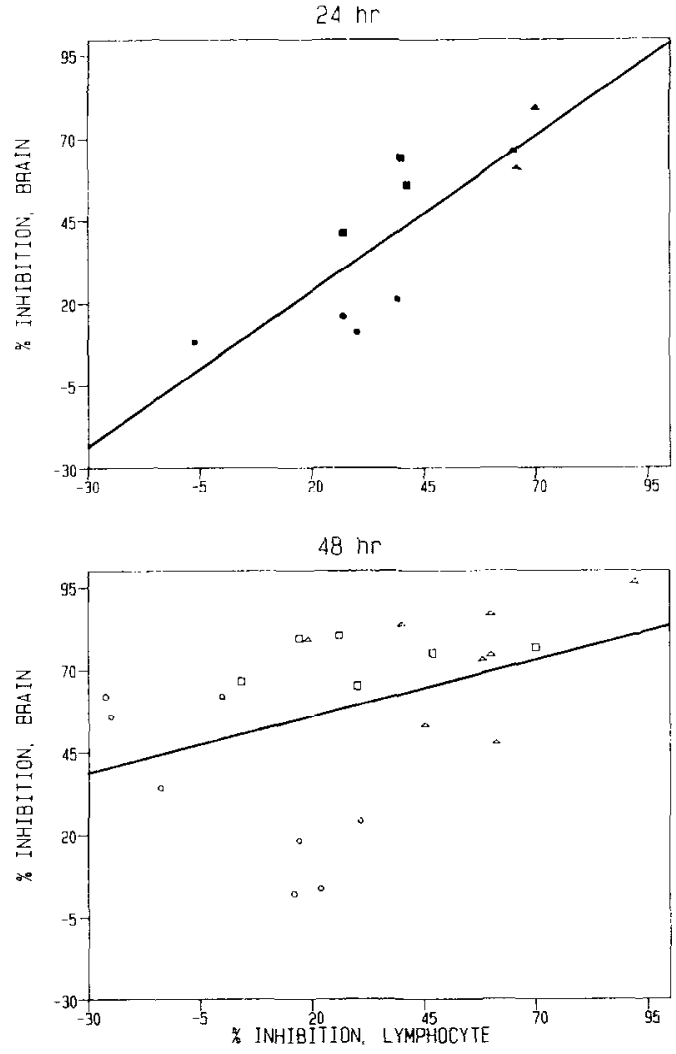

FIG. 1. Linear regression of percentage inhibition of brain NTE on percentage inhibition of lymphocyte NTE in hens treated po with $10(\bullet), 50(0)$, and $100(\Delta) \mathrm{mg} /$ $\mathrm{kg}$ TOCP at $24 \mathrm{hr}$, or with $10(0), 50(\square)$, and $100(\Delta)$ $\mathrm{mg} / \mathrm{kg} /$ TOCP at $48 \mathrm{hr}$ prior to killing. The regression equation of the 24-hr line $(n=10)$ is $y=0.94 x+4.85$; $r^{2}=0.67, p<0.005$ ( $t$ test). The regression equation of the 48-hr line $(n=22)$ is $y=0.34 x+48.95 ; r^{2}=0.15, p$ $>0.05$ ( $t$ test).

first indication of toxic exposure would be the onset of peripheral neuropathy some weeks following insult. It would be preferable to have a system capable of indicating systemic absorption in much shorter periods of time and sensitive enough to disclose situations which should be interrupted before sufficient exposure had occurred to cause overt toxic damage. In experimental animals, brain NTE inhibition may be reliably measured within a few hours following exposure to axonotoxic organophosphorus compounds at doses below the threshold for detection of clinically apparent neuropathy (Johnson and Richardson, 1983). However, there are practical limitations 

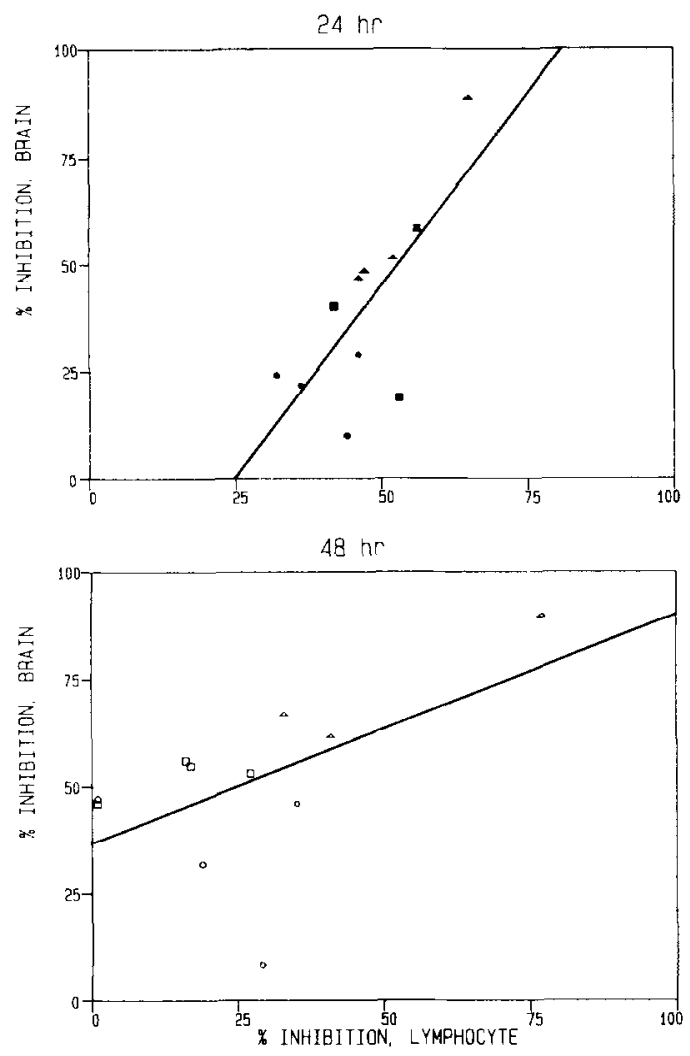

FIG. 2. Linear regression of percentage inhibition of brain NTE on percentage inhibition of lymphocyte NTE in hens treated po with $25(0), 75$ (घ), and $150(\Delta) \mathrm{mg} /$ $\mathrm{kg}$ leptophos at $24 \mathrm{hr}$, or with $25(\mathrm{O}), 75(\square)$, and $150(\triangle)$ $\mathrm{mg} / \mathrm{kg}$ leptophos at $48 \mathrm{hr}$ prior to killing. The regression equation of the 24 -hr line $(n=11)$ is $y=1.78 x$ $-44.15 ; r^{2}=0.53, p<0.02$ ( $t$ test $)$. The regression equation of the 48-hr line $(n=11)$ is $y=0.53 x+36.75 ; r^{2}=0.30$, $p>0.05$ ( $t$ test).

to a brain assay. Clearly, it is usually not possible or desirable to obtain central nervous system tissue from patients. Likewise, in studies with experimental animals, obtaining data on brain NTE inhibition often entails killing one group of animals while a pair-dosed group is used for further procedures. Our present and past (Richardson and Dudek, 1983) observations suggest that assay for inhibition of lymphocyte NTE up to $24 \mathrm{hr}$ after exposure to an organophosphorus compound may be used in lieu of assay of brain tissue to indicate the axonopathic potential of an exposure. An obvious advantage of lymphocyte monitoring is that tissue for assay may be obtained relatively innocuously.
While lymphocyte measurements have good potential as a monitor of acute exposures to axonotoxic organophosphorus compounds in both experimental and clinical situations, our results suggest that lymphocyte NTE assays are limited in their applicability with respect to the period between exposure and measurement. At $48 \mathrm{hr}$ after exposure, there is poor correlation between NTE inhibition in brain versus lymphocytes and it is not likely that much insight about the exposure or its consequences could be gained from lymphocyte assay at this time point. The unsatisfactory correlation between brain and lymphocytes $48 \mathrm{hr}$ after an acute dose of an axonotoxic
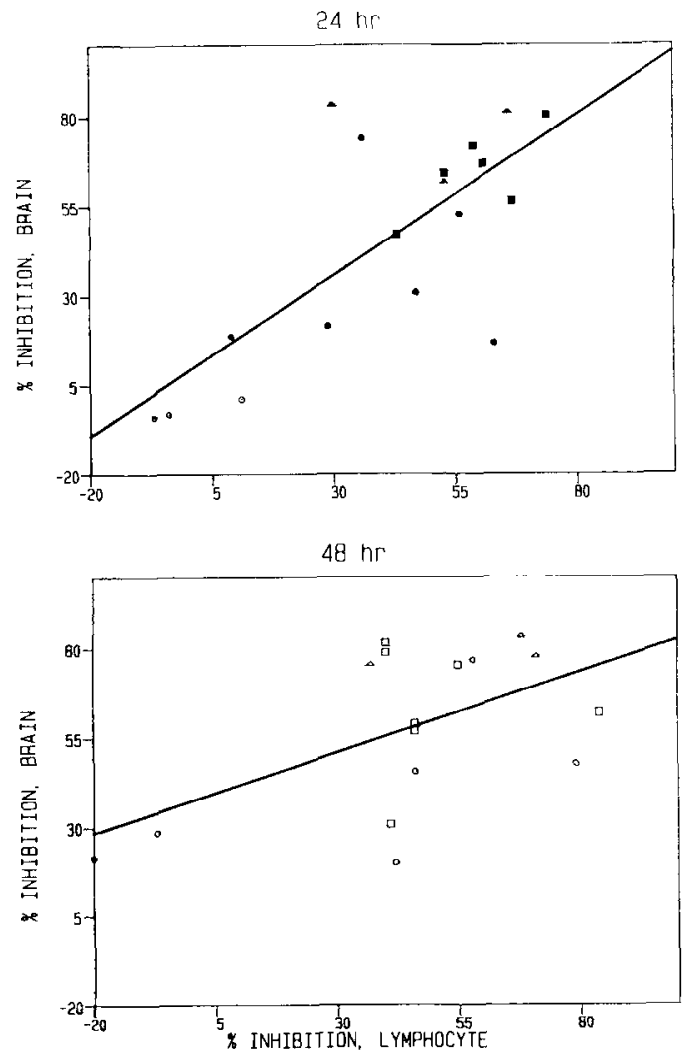

Fig. 3. Linear regression of percentage inhibition of brain NTE on percentage inhibition of lymphocyte NTE in hens treated po with $1.0(\odot), 2.0(\odot), 3.0(\square)$, and 4.0 (A) $\mathrm{mg} / \mathrm{kg} \mathrm{DBDCV}$ at $24 \mathrm{hr}$, or with 2.0 (O), 3.0 ( $\square$ ), and $4.0(\triangle) \mathrm{mg} / \mathrm{kg} \mathrm{DBDCV}$ at $48 \mathrm{hr}$ prior to killing. The regression equation of the 24-hr line $(n=18)$ is $y=0.89 x$ $+8.92 ; r^{2}=0.53, p<0.001$ ( $t$ test). The regression equation of the 48-hr line $(n=16)$ is $y=0.45 x+37.42 ; r^{2}=0.30$, $p<0.05$ ( $t$ test). 

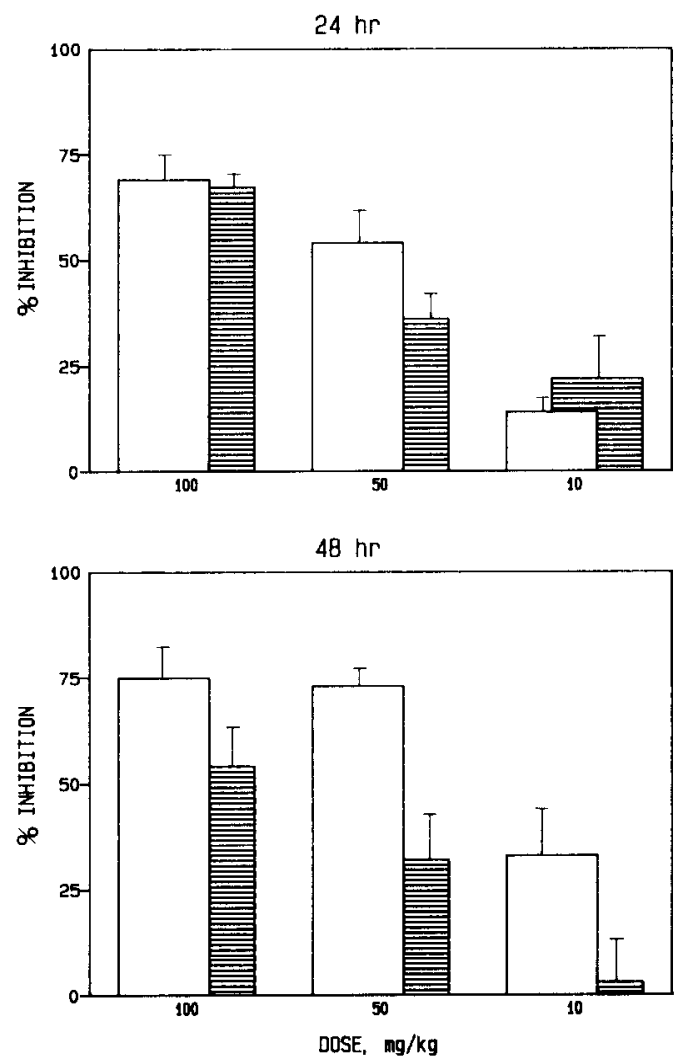

FIG. 4. Mean percentage inhibition ( \pm SE) of brain ( $\square$ ) and lymphocyte (를 NTE in hens given 10,50 , or 100 $\mathrm{mg} / \mathrm{kg}$ TOCP po, either 24 or $48 \mathrm{hr}$ prior to killing. At 24 $\mathrm{hr}$, there were no significant differences between brain and lymphocyte NTE inhibitions at $100(n=3)$ or $10 \mathrm{mg} / \mathrm{kg}$ $(n=4)$, but lymphocyte NTE inhibition was significantly less than brain NTE inhibition at $50 \mathrm{mg} / \mathrm{kg}(n=3, p$ $<0.05$; paired $t$ test). At $48 \mathrm{hr}$, mean percentage inhibition of lymphocyte NTE was consistently lower than that for brain in all dosage groups; the differences were significant (paired $t$ test) for $100 \mathrm{mg} / \mathrm{kg}(n=8, p<0.05)$ and $50 \mathrm{mg} /$ $\mathrm{kg}(n=6, p<0.01)$, but not for $10 \mathrm{mg} / \mathrm{kg}(n=8, p$ $>0.05)$.

organophosphorus compound is reminiscent of the lack of correspondence between brain and lymphocyte inhibition reported by Lotti and Johnson (1980) following subchronic exposure of hens to mono-2-cresyl diphenyl phosphate. It would be profitable to study the biological events which undo correlation between brain and lymphocyte NTE at $48 \mathrm{hr}$, in case they might in some way be circumvented. An alternative approach may be to use another blood component with NTE activity, such as platelets (Bleeker et al., 1983; Richardson and Dudek, 1983), but studies on the stability and dose dependency of inhibition of NTE in these blood elements are incomplete.

Animals killed $48 \mathrm{hr}$ after exposure to the test compounds also had consistently less NTE inhibition in lymphocytes relative to brain. We presume that the divergence of brain and lymphocyte NTE inhibition is due to dissimilar kinetics of reappearance of enzyme activity. Return of activity of an inhibited enzyme may proceed by reactivation of the inhibited en-
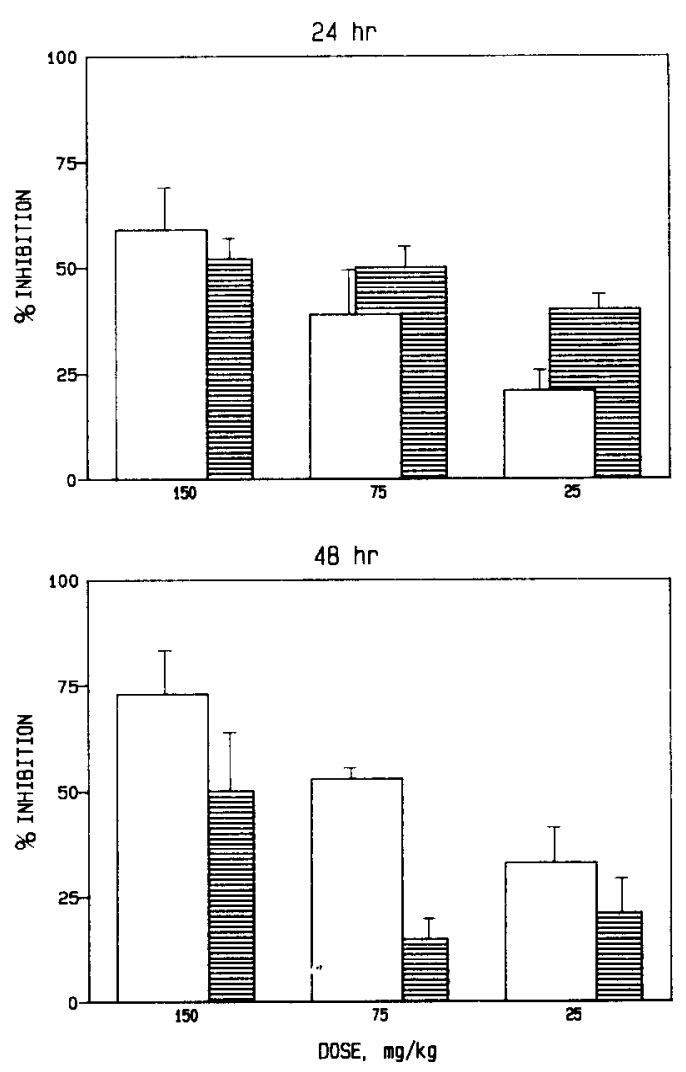

FIG. 5. Mean percentage inhibition ( \pm SE) of brain ( $\square$ ) and lymphocyte (圈) in hens given 25,75 , or $150 \mathrm{mg} / \mathrm{kg}$ leptophos po, either 24 or $48 \mathrm{hr}$ prior to killing. At $24 \mathrm{hr}$, there were no significant differences between brain and lymphocyte NTE inhibitions at $150(n=4)$ or $75 \mathrm{mg} / \mathrm{kg}$ $(n=4)$, but lymphocyte NTE inhibition was significantly greater than brain NTE inhibition at $25 \mathrm{mg} / \mathrm{kg}(n=4, p$ $<0.05$; paired $t$ test). At $48 \mathrm{hr}$, mean percentage inhibition of lyphocyte NTE was consistently lower than that for brain in all dosage groups; the difference was significant (paired $t$ test) for $75 \mathrm{mg} / \mathrm{kg}(n=4, p<0.005)$, but not for $150(n=3)$ or $25 \mathrm{mg} / \mathrm{kg}(n=4)$. 

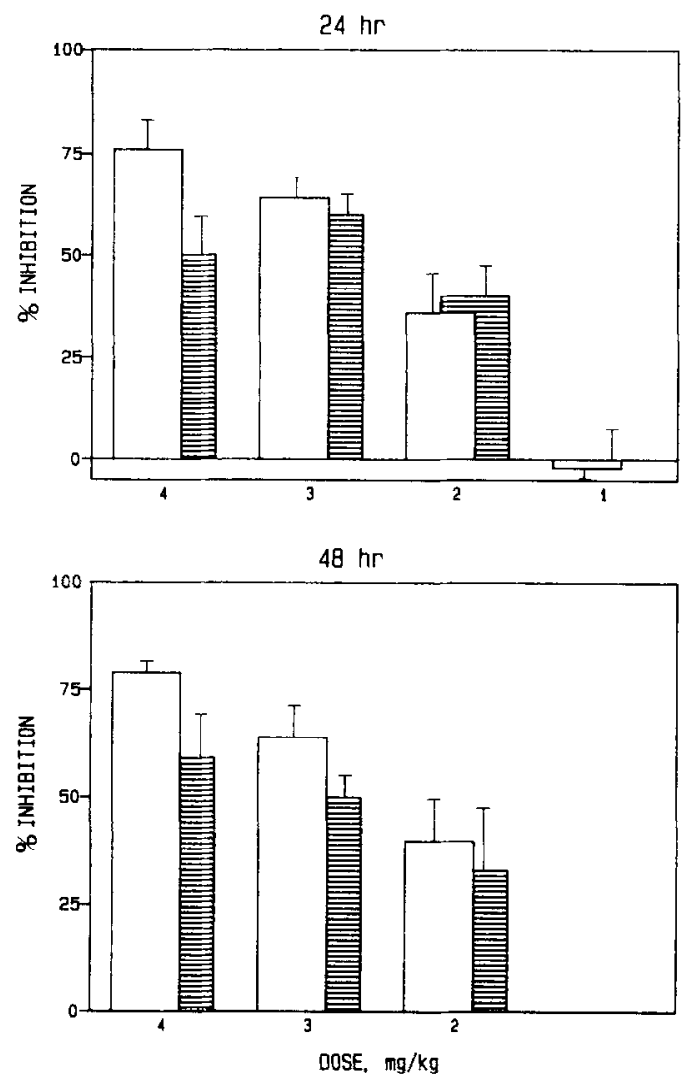

FIG. 6. Mean percentage inhibition ( \pm SE) of brain $(\square)$ and lymphocyte (住) NTE in hens given $1.0,2.0,3.0$, or $4.0 \mathrm{mg} / \mathrm{kg} \mathrm{DBDCV}$ po at $24 \mathrm{hr}$ prior to killing, or 2.0 , 3.0 , or $4.0 \mathrm{mg} / \mathrm{kg} \mathrm{DBDCV}$ po at $48 \mathrm{hr}$ prior killing. At 24 $\mathrm{hr}$, there were no significant differences $(p>0.05$, paired $t$ test) between brain and lymphocyte NTE inhibition for any dosage group ( $n=3,6,6$, and 3 for the 1.0, 2.0, 3.0, and $4.0 \mathrm{mg} / \mathrm{kg}$ groups, respectively). At $48 \mathrm{hr}$, mean percentage inhibition of lymphocyte NTE was consistently lower than that for brain in all dosage groups; the difference was significant (paired $t$ test) for $3.0 \mathrm{mg} / \mathrm{kg}$ ( $n=7, p$ $<0.05)$, but not for $4.0(n=3)$ or $2.0 \mathrm{mg} / \mathrm{kg}(n=6)$.

zyme, de novo enzyme (protein) synthesis, or turnover of cells containing the activity. Resynthesis of enzyme is believed to be the mechanism of return of NTE activity in neural tissue, as reactivation by dephosphorylation has been shown to be slight and nervous system tissue is not comprised of cell populations with high rates of turnover (Johnson, 1982; Richardson, 1984). The relative contributions of different mechanisms for recovery of NTE activity in lymphocytes have not been studied. In contemplating such studies, one should consider more than the normal rates of protein or cell turnover in lymphocytes. Indeed, there are reports indicating that treatment with organophosphorus compounds may alter the function or the constituents of the lymphocyte population (Watanabe and Sharma, 1977; Foil et al., 1981; Ehrich and Gross, 1983).

Comparative studies of avian and mammalian systems using both acute and chronic exposures may be useful in interpreting results of lymphocyte NTE measurements in humans. Lotti et al., (1983) have conducted a field study of seven workers exposed daily for up to 34 days to $S, S, S$-tributylphosphorotrithiolate (DEF) and tributylphosphorotrithioite (merphos), in which decreases in lymphocyte NTE of approximately $50 \%$ of preexposure values were reported between days 25 and 30 of exposure, with no concomitant signs or symptoms of neurological abnormalities detected in any of the subjects at any time during the exposure or at 3 weeks after termination of exposure. This would indicate a positive response of human lymphocyte NTE following exposure to organophosphorus compounds with experimentally demonstrated axonotoxic potential (Davis et al., 1985). In view of the lack of detectable neurological abnormalities in the exposed humans, the NTE inhibition in each individual's nervous system was presumably below the threshold required for expression of clinical effects, although no neural tissue was available for determination of correlation.

The fact that the NTE assay is quantitative makes it useful for ranking the relative potency of axonopathic organophosphorus compounds as well as discovering axonopathic potential at subclinical doses. However, the oftenquoted "threshold" of approximately $70 \%$ inhibition of whole-brain NTE following an acute exposure (Johnson and Richardson, 1983) should not be taken as an absolute correlate of the dividing line between the subsequent presence or absence of neuropathy. We found that $100 \mathrm{mg} / \mathrm{kg}$ TOCP produced brain NTE inhibitions of 69 and $75 \%$ at 24 and 48 $\mathrm{hr}$, respectively, whereas the ED50 for clinically apparent neuropathy has been reported 
to be 200 to $250 \mathrm{mg} / \mathrm{kg}$ (Aldridge and Barnes, 1961; Watanabe and Sharma, 1976). Neuropathy is not generally seen at lower doses because the dose-response curve for inhibition of hen brain NTE $24 \mathrm{hr}$ after a single oral dose of TOCP rises sharply to an ED50 of $40 \mathrm{mg} /$ $\mathrm{kg}$ and then becomes relatively flat, so that inhibition increases from 70 to $95 \%$ between 100 and $1000 \mathrm{mg} / \mathrm{kg}$; to ensure obvious clinical neuropathy, doses of 500 to $1000 \mathrm{mg} / \mathrm{kg}$ are commonly used (Dudek, 1979). Likewise, Lotti and Johnson (1980) found that 80 to $90 \%$ inhibition is required for unequivocal clinical neuropathy from single oral doses of mono2-crcsyl diphenylphosphate.

Route of administration and chemical purity may affect the amount of active inhibitor that reaches the target, so that the inclusion of NTE inhibition data is much more informative than merely stating the dose required to produce neuropathy. Thus, we found that dosing po with $3.0 \mathrm{mg} / \mathrm{kg}$ DBDCV produced only $64 \%$ inhibition of brain NTE at $24 \mathrm{hr}$, but in independent work in our laboratory (Huggins, 1982) dosing sc with $2.8 \mathrm{mg} / \mathrm{kg}$ DBDCV was sufficient to produce $>80 \%$ inhibition of brain NTE at $24 \mathrm{hr}$, with $100 \%$ incidence of frank neuropathy. Similarly, using purified leptophos given po, we found that $150 \mathrm{mg} / \mathrm{kg}$ inhibited brain NTE only $59 \%$ at $24 \mathrm{hr}$ and $73 \%$ at $48 \mathrm{hr}$. The minimum effective dose for neuropathy of highly purified leptophos given in a single po dose was reported by Hollingshaus et al. (1979) to be 250 $\mathrm{mg} / \mathrm{kg}$. The corresponding value for technical grade leptophos has been determined to be 100 $\mathrm{mg} / \mathrm{kg}$, which is consistent with the presence of impurities in this preparation (e.g., desbromoleptophos) known to be more potently axonotoxic than leptophos itself (Abou-Donia, 1979). Unfortunately, no NTE measurements were included in the latter two studies.

Perhaps the most important point to consider regarding the threshold issue is that virtually all of the currently available data on the axonotoxic potential of organophosphorus compounds are based on gross clinical observation as the indicator of neuropathy (Davis et al., 1985). A careful examination of more objective and quantifiable endpoints such as histopathological and electrophysiological changes would be helpful in determining whether subclinical damage is produced by lower levels of NTE inhibition than have heretofore been associated with the production of neuropathy.

Future work on lymphocyte NTE should further explore the advantages and limitations of its use as a biomonitor of axonotoxic organophosphorus compound exposure. Moreover, the possibility that NTE may be involved in functional or pathological interrelationships between the nervous system and the immune system certainly deserves further study (Dudek and Richardson, 1982). Proteins expressed in greatest concentration in brain and lymphocytes, such as NTE (Dudek and Richardson, 1982; Williams, 1983), may be part of such relationships as has been demonstrated or postulated for other proteins with similar distribution (Barclay and Hydén, 1978; Golub, 1982; McKenzie et al., 1982).

\section{ACKNOWLEDGMENTS}

This work was supported by Grants 2RO1 ES01611 and 1RO1 ESO2770 from the National Institutes of Health/ National Institute of Environmental Health Sciences. The authors thank Dr. R. B. Conolly and Ms. K. M. Richardson for their highly constructive comments on the manuscript.

\section{REFERENCES}

ABOU-DoniA, M. B. (1979). Delayed neurotoxicity of phenylphosphonothioate esters. Science (Washington, D.C.) 205, 713-715.

ALDRIDGE, W. N., AND BARNES, J. M. (1961). Neurotoxic and biochemical properties of some triaryl phosphates. Biochem. Pharmacol. 6, 177-188.

BARCLAY, A. N., AND HYDEN, H. (1978). Localization of the Thy- 1 antigen in rat brain and spinal cord by immunofluorescence. J. Neuorochem. 31, 1375-1391.

Bertoncin, D., Russolo, A., CARoldi, S., AND lotTi, M. (1985). Neuropathy target esterse in human lymphocytes. Arch. Environ. Health 40, 139-144.

BLEEKER, M. L., MARONI, M., AND SEPANSKI, M. (1983). A biologic marker for organophosphate exposure: Neurotoxic esterase activity in human lymphocytes and platelets. In Developments in the Science and Practice of Toxicology (A. W. Hayes, R. C. Schnell, and T. S. Miya, eds.), pp. 507-512. Elsevier, Amsterdam.

BRADFORD, M. M. (1976). A rapid and sensitive method 
for the quantitation of microgram quantities of protein utilizing the principle of protein-dye binding. Anal. Biochem. 72, 248-254.

DAVIS, C. S., JOHNSON, M. K., AND RiChARDSON, R. J. (1985). Organophosphorus compounds. In Neuroluxicology of Industrial and Commercial Chemicals (J. L. O’Donoghue, ed.), Vol. II, pp. 1-23. CRC Press, Boca Raton, Fla.

Davis, C. S., ANd Richardson, R. J. (1980). Organophosphorus compounds. In Experimental and Clinical Neurotoxicology (P. S. Spencer and H. H. Schaumburg, eds.), pp. 527-544. Williams \& Wilkins, Baltimore.

DUDEK, B. R. (1979). Brain and Leucocyte Neurotoxic Esterase as Biomonitors of Organophosphorus Delayed Neurotoxicity. Ph.D. thesis, The University of Michigan, pp. 63-64, University Microfilms International, Ann Arbor.

DudeK, B. R., BARTh, M., GePhart, L., Huggins, J., AND RICHARDSON, R. J. (1979). Correlation of brain and lymphocyte neurotoxic esterase inhibition in the adult hen following dosing with neurotoxic compounds. Toxicol. Appl. Pharmacol. 48, A198.

DUDEK, B. R., AND RICHARDSON, R. J. (1980). Lymphocyte and brain neurotoxic esterase: in vitro similarities. Toxicology Letters S.1, 134.

DUDEK, B. R., AND RICHARDSON, R. J. (1982). Evidence for the existence of neurotoxic esterase in neural and lymphatic tissue of the adult hen. Biochem. Pharmacol. 31, 1117-1121.

EIRICI1, M., AND Gross, W. B. (1983). Modification of triorthotolyl phosphate toxicity in chickens by stress. Toxicol. Appl. Pharmacol. 70, 249-254.

Ellman, G. L., Courtney, K. D., Andres, V., and Featherstone, R. M. (1961). A new and rapid colorimetric determination of acetylcholinesterase activity. Biochem. Pharmacol. 7, 88-95.

Forl, L. D., Chambers, H. W., Stinson, R. S., AND GLICK, B. (1981). Immunological aspects of tri-o-tolyl phosphate-induced delayed neurotoxicity in chickens. Toxicol. Appl. Pharmacol. 56, 259-264.

GoldSTEIN, A. (1964). Biostatistics: An Introductory Text, pp. 144-146. Macmillan, New York.

Golub, E. S. (1982). Connections between the nervous, hematopoietic and germ-cell systems. Nature (London) 299, 483.

Hollingshaus, J. G., ABU-El-HaJ, S., and Fukuto, T. R. (1979). Delayed neurotoxicity of $O$-alkyl $O$-aryl phenylphosphonothioate analogues related to leptophos administered orally to the hen. Agric. Food Chem. 27, 1197-1201.

HugGins, D. J. (1982). Central Nervous System Endogenous Phosphorylation in Organophosphorus Delayed Neuropathy. Ph.D. thesis, The University of Michigan, pp. 37-38, University Microfilms International, Ann Arbor.

JoHNSON, M. K. (1974). The primary biochemical lesion leading to the delayed neurotoxic effects of some organophosphorus esters. $J$. Neurochem. 23, 785-789.

JoHNSON, M. K. (1977). Improved assay of neurotoxic esterase for screening organophosphates for delayed neurotoxicity potential. Arch. Toxicol. 37, 113-115.

JOHNSON, M. K. (1982). The target for initiation of delayed neurotoxicity by organophosphorus esters: Biochemical studies and toxicological applications. Rev. Biochem. Toxicol. 4, 141-212.

JOHNSON, M. K., AND RICHARDSON, R. J. (1983). Biochemical endpoints: Neurotoxic esterase assay. Neurotoxicology 4, 317-326.

LOTTI, M., BeCKER, C. E., AMINOFF, M. J., WOODROW, J. E., SEIBER, J. N., TAlCotT, R. E., AND Richardson, R. J. (1983). Occupational exposure to the cotton defoliants DEF and merphos: A rational approach to monitoring organophosphorus-induced neurotoxicity. J. Occup. Med. 25, 517-522.

LotTI, M., AND Johnson, M. K. (1978). Neurotoxicity of organophosphorus pesticides: Predictions can be based on in vitro studies with hen and human enzymes. Arch. Toxicol. 41, 215-221.

LOTT, M., AND JOHNSON, M. K. (1980). Repeated small doses of a neurotoxic organophosphate: Monitoring of neurotoxic esterase in brain and spinal cord. Arch. Toxicol. 45, 263-271.

McKenzie, J. L., Dalchau, R., AND Fabre, J. W. (1982). Biochemical characterization and localization in brain of a human brain-leucocyte membrane glycoprotein recognized by a monoclonal antibody. $J$. Neurochem. 39, 1461-1466.

RICHARDSON, R. J. (1984). Neurotoxic esterase: Normal and pathogenic roles. In Cellular and Molecular Neurotoxicology (T. Narahashi, ed.), pp. 285-295. Raven Press, New York.

RICHARDSON, R. J., AND DUDEK, B. R. (1983). Neurotoxic esterase: Characterization and potential for a predictive screen for exposure to neuropathic organophosphates. In Pesticide Chemistry: Human Welfare and the Environment (J. Miyamoto and P. C. Kearny, eds.), pp. 491496. Pergamon, Oxford.

SCHWAB, B. W., AND MURPHY, S. D. (1981). Induction of anticholinesterase tolerance in rats with doses of disulfoton that produce no cholinergic signs. $J$. Toxicol. Environ. Health 8, 199-204.

Watanabe, P. G., AND ShaRMA, R. P. (1976). Lymphatic tissue response in chickens treated with tri- $\alpha$-tolyl phosphate. J. Toxicol. Environ. Health 1, 777-786.

Watanabe, P. G., AND Shakma, R. P. (1977). Tri-o-tolyl phosphate neurotoxicity: Lack of evidence for autoimmunologic involvement. Arch. Environ. Contam. Toxicol. 6, 233-240.

Williams, D. G. (1983). Intramolecular group transfer is a characteristic of neurotoxic esterase and is independent of the tissue source of the enzyme. Biochem. $J .209$, 817-829. 